\title{
Collective Bargaining System in the Game between Labor and Capital: Vacancy and Reconstruction
}

\author{
Qiuxia $\operatorname{Tan}^{1}$ \\ ${ }^{1}$ School of Law, University of Jinan (West Campus), Jinan, China \\ Correspondence: Qiuxia Tan, School of Law, University of Jinan (West Campus), No.106 Jiwei Road, Jinan \\ 250022, Shandong, China. E-mail: sl_tanqx@ujn.edu.cn
}

Received: February 5, $2013 \quad$ Accepted: March 11, $2013 \quad$ Online Published: April 27, 2013
doi:10.5539/ass.v9n5p128

This paper is a periodical achievement of Shandong social sciences planning project "Collective Bargaining System in the Game between Labor and Capital: Vacancy and Reconstruction" (12CFXJ09)

\begin{abstract}
Implementation of collective bargaining system in China is not only an issue of straightening out the labor relationship, but an economic issue of economics and even a social issue. In China, a lot of difficulties still exist in implementation of collective bargaining system, including obstacles in terms of system and obstruction in terms of institution. The three labor rights are the basis and guarantee of collective bargaining system and collective bargaining separating from the three labor rights may cause the system to be a mere formality. An analysis of the reasons for vacancy in the collective bargaining system can be reconstructed from the following three aspects, namely, prescribing the right to strike of laborers, reforming the current wage system and funds system of the trade unions, positively carrying out industrial collective bargaining and promoting establishment of multi-level collective bargaining to help resolve predicament in collective bargaining faced up in China.
\end{abstract}

Keywords: collective bargaining, vacancy, reconstruction

Collective bargaining system is an important guarantee for effective running of the labor force market mechanism and is able to make up for disadvantages in labor legislation and further improve the labor contract. Labor organization and employer organization bargain on such labor conditions as remuneration of labor, working hour and vocation taking to create a benign atmosphere for labor and capital cooperation. In this way, slowdown and strike may be avoided with low costs to achieve the purpose of maintaining laborers' interest and a harmonious labor and capital relationship.

\section{An Analysis of the Current Domestic Research}

Domestic scholars have made profound research and analysis in the collective bargaining system in China and propose a series of theories. At present, domestic research on the collective bargaining theory is mainly concentrated on the following several aspects:

\subsection{Research on the Nature of Collective Bargaining System}

Research on the nature of collective bargaining system has, in the recent years, received wide attention in the academic world. Nevertheless, generally speaking, not only extant achievements are few, but also they are not systematic. Representative academic achievement was only the three hypotheses on the nature of collective bargaining system proposed by She Yunxia from China Institute of Industrial Relations. It is a pity that she hasn't made a definite demarcation on the nature of collective bargaining system.

\subsection{Problems and Institutional Obstacles Encountered in the Process of Promoting Collective Bargaining}

Problems and institutional obstacles encountered in the process of promoting collective bargaining become the core issue in research on collective bargaining system. According to Luo Tianhu from Northwestern Polytechnical University, the function of collective bargaining system is to establish fair and reasonable labor standard and labor condition. However, under the integration mode, on one hand, the government restrains the space of self-governing for both the two parties of labor and capital. On the other hand, the government formulates a lot of legislation to establish labor standard and labor condition and sets up corresponding 
supervision mechanism to ensure compliance and implementation of the law. This practice of "exceeding the due duties and meddling in others' affairs" has made the collective bargaining lose its significance of existence. According to Yao Hong who comes from the State-owned Property Company in Shaoxing City Zhejiang Province, the main reason for difficulties in promoting collective bargaining is that the subject fails to be in the proper position. All the above achievements only make a conclusion on problems encountered, but still lack deep study and discussion.

\subsection{Research on Development and Improvement of Collective Bargaining System}

In statement of development and improvement of the collective bargaining system, Cheng Yanyuan who comes from Renmin University of China believes that effective running of collective bargaining system can neither go without independence and development of the trade union and the employer organization nor be possible without reformation of the working mode of the current trade union. According to Guo Yue who comes from the Institute of Labor and Social Sciences, Ministry of Human Resources and Social Security of PRC, promotion of the collective bargaining and realization of balance in the labor relationship has to strengthen power of workers. Establishment and development of the above theories has vigorously facilitated development and improvement of collective bargaining system and has important guidance meaning for us to vigorously promote the collective bargaining system and promote establishment of a harmonious and stable labor relationship. It has also laid a good foundation for further research on the collective bargaining system.

\section{Research Methodology}

\subsection{Literature Research}

Through literature research and grasping basic materials for development of the collective bargaining system, we attempt to make study of this project have a higher starting point.

\subsection{Interview Survey}

Through interview with Jinan City Federation of Trade Unions, representative enterprise trade union chairmen in promotion of collective bargaining, enterprise capital representatives and workers, we have meticulously mastered the first hand data in the process of collective bargaining and deeply understood obstacles and difficulties encountered in current promotion of collective bargaining and collective contract system in China. The interview has enabled the writer to have deeper comprehension in the collective bargaining in terms of both theory and practice.

\subsection{Systematic Research with Comprehensive Application of Questionnaire Survey and Case Study Analysis}

This study has summarized experiences and found out disadvantages by means of making a profound analysis of the case study and questionnaire survey in collective bargaining about salary in the catering industry in Wuhan and in collective bargaining in Honda in Nanhai.

\section{Causes for Vacancy in Collective Bargaining System in China}

"Implementation of collective bargaining in China is not only an issue of straightening out the labor relationship, but also an economic issue and even a social issue. It will be closely correlated with whether the labor relationship can be kept in a harmonious and stable condition, the completeness of the market economic system and even significant strategic decision making deployment of the entire country." (Yi Bing \& Yue Shui, May 10, 2011) Nevertheless, it has to be admitted that, objectively speaking, there are still a lot of difficulties in collective bargaining, not only including social consensus issues, but also including difficulties in practical operation and not only including obstacles in terms of system, but also including obstruction in terms of institution. The causes for vacancy in the collective bargaining in China mainly contain the following:

\subsection{Insufficient Independence and Representativeness of the Trade Union Affects Its Role Playing}

It is true that the trade union is the bargaining subject in law, but as a result of the proverbial reasons, the trade union lacks the energy of motion to fundamentally safeguard the legal rights for laborers and independence and representativeness of the trade union is the largest obstacle encountered in collective bargaining. In essence, the collective bargaining system is to build a platform for communication and exchange between the two parties of labor and capital and create power for the labor party through the trade union to contend against the enterprise. It has been proved by foreign practice and experience that, only when the trade union becomes an independent bargaining subject and has the bargaining capacity equivalent to the enterprise, can collective bargaining be really in function and play its due role. Currently, countless relations still exist between the trade union in the enterprise and the enterprise, so it is quite difficult for the trade union to become an independent subject in collective bargaining. This is mainly manifested in the following three facts. Firstly, construction of the trade 
union organization depends too much on the enterprise. According to practice, construction of the trade union is the premise and guarantee for the collective contract system. With development of the economy with different types of ownership and diversification of the forms of employment, construction of the trade union is faced with enormous challenges. However, the organizational mode of the trade union has not been changed accordingly and more emphasis is put on persuasion and education on enterprise operators. Whether construction of the trade union is merely regarded as one of the jobs of the enterprise and one of the indicators for performance appraisal of the enterprise, while there is no investigation of corresponding responsibility. In addition, propaganda and education among enterprise employees is neglected, which leaves a hidden danger for the enterprise not to set up the trade union and to manipulate and control the trade union even if it is set up. Secondly, the trade union organization is subordinate to the enterprise. After its establishment, the trade union is often classified as one section of the administrative institutions of the enterprise and its working strategy and target naturally keeps consistent with the enterprise, as a result of which the trade union loses its independence in the organization. Thirdly, the labor relationship of the members in the trade union depends on the enterprise. The members of the trade union have a dual identity, one identity as an employee of the enterprise and the other identity as a staff representative. The wage and welfare of the members in the trade union is determined by the enterprise and the labor relationship is also controlled by the enterprise, which brings insuperable difficulties for the members in the trade union to perform their responsibility of safeguarding the legal rights and interests of the employees. When the trade union comes into a conflict of rights with the enterprise or puts in a good word for the employees, it is quite possible to lead to tension in the work relationship between the trade union and the enterprise. As a consequence, the enterprise may not support the work of the trade union or the members in the trade union of the enterprise are dismissed from the office and even the enterprise may relieve the labor relationship of the members of the trade union with a variety of excuses. (Special Research Group of Harbin City Federation of Trade Unions, 2007) In the situation when the law has no appropriate protection on the members in the trade union, such a relationship between the members of the trade union and the enterprise is another important reason for the trade union to have difficulty in being independent.

\subsection{Vacancy of the Right to Strike in the Legislation and Lack of Action Guarantee in Protection of the Right}

There is no stipulation on the issue of "strike" in the existing "Constitution", "Labor Law" and "Collective Contract Provisions" in China until vague prescriptions were made in Article 27 in the modified "Trade Union Law" in 2001, "When shutdown and slowdown happen in the enterprise and the public institution, the trade union should negotiate with the enterprise, the public institution or related sections on behalf of the staff to reflect opinions and requirements of the staff and propose opinions of resolution". Using the words "shutdown, slowdown" to replace "strike", the legislators expected to avoid any fierce contradiction accident, which is understandable. Nevertheless, legislation by means of merely such a beautiful wish is of no realistic meaning to avoid occurrence of conflict and contradiction and what should happen will still happen. The "Outlook Weekly" wrote in December 2009, "The mass disturbance triggered by labor and capital contradiction left a deep impression on the public with a more fierce and violent form in 2009." As a matter of fact, confirming the right to strike in legislation is the need to better resolve labor conflict. Due to deepening of the reform and globalization of the development of market economy, friction in labor relationship happens occasionally. The quantity of collective petition and mass disturbance triggered by labor dispute increases and expands in terms of scale. (Dong Baohua, 2007) However, as a result of the vague prescription on the right to strike, such contradictions are more likely to evolve to mass disturbances of petition, sit-down strike and ring-fencing the government agency in a disorderly and spontaneous condition, which may lead to more serious social impacts and more harmful influences. Prescription on the right to strike is not to encourage happening of strike, but to standardize this action through law and direct it to play a better role. It is not difficult from the coordination mechanism that confirming of the right to strike has not caused frequent happening of strike, but has better realized a benign labor relationship. (Wang Lin, 2008)

\section{The Basis and Guarantee for Collective Bargaining System}

The three labor rights are the basis and guarantee for the collective bargaining system. The three labor rights usually refer to the three rights that the two parties of labor and capital both share, namely, the right to organize, the right of collective bargaining and the right to strike. The right of collective bargaining is the core right of the three, the right to organize is the premise and the right to strike is the guarantee.

\subsection{The Right to Organize}

The right to organize is the basic right that the "Constitution" and the "Labor Law" endow to laborers, a right that the laborers organize and participate in the trade union to ensure independent running of the trade union, and 
is the basis of the right to strike. Although the right to organize is shared by the laborers, the laborers themselves are not entitled to exercise this right and it is exercised by the collective organization of the laborers - the trade union. The right to organize is an "antecedent behavior" of collective bargaining. In order to have a collective bargaining, the laborers have to unite to organize the trade union. Hence, the right to organize does not take organization of an association as its ultimate target, but a necessary "antecedent behavior" for conducting a collective bargaining. (Cheng Yanyuan, 2008) The right to organize in labor is distinguished from a common right of freedom in an association, the right to organize in labor has the significance of survival right and labor right and it does not take pursuit of ambitious objectives in politics, economy and culture as the ultimate target.

\subsection{The Right of Collective Bargaining}

The right of collective bargaining is a kind of right that an industrial country and region endows to its laborers. Collective bargaining is one of the core issues in the contemporary labor-capital relationship. Collective bargaining means the labor party negotiates with the capital party on labor conditions by way of the trade union. The bargaining result has a legal binding force which the two parties have to follow. The purpose is that the two parties of labor and capital can conclude labor conditions on an equal basis to guarantee the rights and interests of the laborers. Collective bargaining not only confirms formal rules for adjustment of the labor relationship, but also a sort of mechanism to resolve conflict. Collective bargaining is able to effectively encourage the two parties of labor and capital to make a concession, reach a consensus and sign an agreement. The cost is not only low but also quite effective in resolving labor-capital contradictions in the period of social transition through collective bargaining.

\subsection{The Right to Strike}

The right to strike, also termed as the right of collective dispute or the right of collective action, is a right of collective confronting action that the two parties of labor and capital fulfill their own assertion and requirement in the labor and capital relationship and adopt appropriately strike or slowdown to block normal operation of the enterprise. In a general sense, the right of collective dispute by laborers contains strike, collective slowdown and occupying the factory, etc. In a narrow sense, the collective dispute right is a right that the laborers strike. Strike in a legal sense is aimed at improving the labor conditions or obtaining other economic interests as well as signing a collective contract. After the Second World War, the right to strike became a right of the citizens generally recognized by countries with a market economy system and relative international conventions and local legislations also confirmed the right to strike. The laborers share the right to strike protected by the law, which is helpful for protecting the laborers' right of collective bargaining and signing a collective contract and which also helps to confirm the demarcation line between illegal strike and legal strike and further helps the legal and standard behavior of strike. It is necessary to make legal regulations on any illegal strike to reduce negative influences of illegal strike on the laborers, the employment unit and the entire society.

The right to strike is closely correlated with the right of collective bargaining and is the guarantee whether collective bargaining gains substantial success or not. Implementation of the right to strike usually occurs in conclusion, performing or alteration of the collective contract in the process of collective bargaining. Collective bargaining should exert pressure means and the right to strike is the final most effective pressure means of the laborers. In the legal labor system, the right to organize, the right of collective bargaining and the right to strike altogether constitute the collective rights of the laborers. These three labor rights mutually correlate and guarantee. The right to organize is the premise and the basis, the right of collective bargaining is the center and the right to strike is the final guarantee. "In reality, any collective bargaining breaking away from the three labor rights might cause this system to be merely a formality. As a result, on one hand, the contract may be propelled on a large scale, but, on the other hand, conflict of labor and capital may be continuously escalated." (Wang Jing, 2011)

\section{Reconstruction of the Collective Bargaining System in China}

The reason why the target of the labor legislation in China has been unable to be completely fulfilled is that the labor legislation in China has not completely followed the objective historical rule of the legal labor relationship and has failed to fully relied on collective bargaining to balance the labor-capital power. In the meantime, the labor legislation has excessively constrained the rights of laborers and capital in some aspect, and constraint on capital sometimes seems too rigorous. The government deals with the labor and capital relationship with an excessive interference method and sometimes even ignores the self-governing power of the two parties of laborers and capital, which leads to some problems in the process of setting and implementing the collective bargaining system. A general survey on the collective bargaining system, the author reconstructs from the following three aspects, namely, prescribing the right to strike of laborers, reforming the current wage and funds 
system of the trade union and positively promoting industrial collective bargaining and facilitating construction of multi-level collective bargaining.

\subsection{Prescribing the Right to Strike of Laborers and Strengthening the Bargaining Power of Laborers}

The laborers' right to strike is a kind of self-relief right of the laborers and, different from the "strike" in its political sense, it is a component of the right of labor. The right to strike is a basic right that the law endows to the laborers to contend against the employment unit or employers in certain condition. A large majority of countries in the world have legally affirmed the right to strike of laborers to constrain and prevent any improper conduct of the employers and to standardize the strike behavior of workers by means of defining legal strike conditions. Considering the current labor legislation in China, although it has not explicitly prohibited strike, it has neither legally confirmed the right to strike. Nevertheless, in reality, accidents of shutdown in the form of strike have occurred. Let's take the year 2008 as the example. On March 31, 2008, eighteen scheduled flights from Yuan Branch of China Eastern Airlines that carried out the flight mission of Neizhou in Yunnan Province altogether made a return voyage. On November 3, 2008, the incident of "tax strike to transport" occurred to all taxies in the central downtown in Chongqing. The incident of "tax strike to transport" caused serious inconvenience to the life of citizens in Chongqing. After the incident happened, some tax drivers in other cities also successively "stroke to transport collectively" and simulated the action of tax drivers in Chongqing to safeguard their rights. The legislation should not take an avoidance attitude, but, instead, should bring this fact into the legal norm. Confirming the right to strike of laborers and standardizing the action of strike in pursuant to the law can enable the laborers to propose legal rights to the employment unit by means of legal strike.

From the perspective of legislation, the first thing to do is to modify the current constitution and to explicitly define in the constitution "Citizens of the People's Republic of China have the freedom to strike." This is because the right to strike belongs to a basic right, and it has to be confirmed by the constitution. Meanwhile, only if the constitution makes confirmation on the right to strike, can the common law have the proof for legislation. Then, it is necessary to modify the current trade union law and confirm endowing the trade union with the right to organize a strike. From experiences in other countries or regions, if the trade union is endowed with the right to organize a strike by the legislation which also stipulates specific and feasible rules for the trade union to organize a strike and organizes the strike pursuant to the law, the trade union may better strengthen control over the strike, realize regularization and normalization of the strike and restrain destructive effect of the strike. Finally, "Strike Law of the People's Republic of China" should be formulated. On one hand, this law will make necessary and detailed constraints on the purpose of a strike, the subject of a strike and the behavior of a strike, etc. On the other hand, the law will make scientific and strict stipulations on conditions and procedures to implement the right to strike and let the strike have laws to abide by. (Liu Huaisong, 2010)

\subsection{Reforming the Current Trade Union System and Ensuring Independence and Representativeness of the Trade Union}

The first to reform the current trade union system is to strengthen independence of the trade union, which necessarily clamors for independence of personnel and funds. According to stipulations in "Trade Union Law", the enterprise, public institution and government organ that set up trade union organizations appropriate funds to the trade union worth of $2 \%$ of the total wages of all staff each month and this $2 \%$ is the main source of the trade union funds. However, workers have doubts in the form of the trade union as a result of the funds contributed with the mode of administrative appropriation by the enterprise. Even some workers hold the view that the trade union is the functional department of the trade union instead of a representative of the rights and interests of laborers. And the enterprise believes that the major function of the trade union is to safeguard the rights and interests of laborers and it is irrational to require the enterprise to appropriate part of the trade union's funds, so the phenomenon of defaulting funds of the trade union in reality often occurs. In order to change this situation, it is necessary to ask the staff themselves to pay the funds of the trade union according to the common international convention and to break away from administrative appropriation. In such way, the trade union is able to become an independent legal entity and the workers will have the sense of identity towards the trade union. Furthermore, the members of the trade union come to realize that the trade union is their own organization and if they are able to resolve problems for themselves, it will not occur that someone is worried the members of the trade union is reluctant to pay the membership dues. (Wang Qin, 2006) It is stipulated in Article 41 in "Trade Union Law", "Salary, rewards and subsidy for the full time staff of the council of the trade union in the enterprise, public institution and government organ should be paid by the unit where it is established." Such a mode of salary payment enables the enterprise to take control over the behavior of working staff in the trade union by means of controlling payroll requisition so as to influence the personnel independence of the trade union organization. "All without exception, expenses of the salary of officials in the trade union all over the world come from the 
funds of the trade union. Legislation of the trade union in a lot of countries list the expenses of salary as the primary content of trade union fund." (Chang Kai \& Zhang Derong, 1993) Thus, we should reform the salary system of working staff in the trade union as soon as possible and it depends on the member conference to assess the salary level of cadres in the trade union based on the quality of the job of the trade union to safeguard rights of laborers. (Wang Junling, 2009)

\subsection{Positively Promoting Industrial Collective Bargaining and Facilitating Construction of Multi-level Collective Bargaining Structure}

The current legal regulations only prescribe collective bargaining at the level of enterprise, but haven't made any stipulation on collective bargaining at the level of industry. Given the legal regulations in foreign countries, although they have different emphasis, the structure of multi-level collective bargaining is a common choice. With regards to the current situation of the trade union in the enterprise, implementation of the structure of multi-level bargaining structure can enable the trade union in the enterprise to be more independent so as to avoid excessively formalized disadvantages. Industrial bargaining is applicable in the industry that has relatively a large number of medium and small-sized enterprises or joint bargaining of the trade union or staff representatives and the employers in multiple enterprises can be also implemented. In large and medium-sized enterprises, internal bargaining can be regarded as the superior choice. Given the grass-root, local and industrial trade union's organizational structure, industrial trade union has obvious superiorities as it is able to fully embody the functions of the trade union. In the meantime, collective contract at the level of industry has a positive effect on the collective bargaining at the level of enterprise.

The collective bargaining in China in the future will mainly focus on industrial collective bargaining. With development of the market economy in depth and breadth, the status and effect of industrial collective bargaining will become more prominent and important. Implementation of industrial collective bargaining in good order may set appropriate "access threshold" for development of industry with gradual improvement of labor productivity. "It is necessary to eliminate those low-end enterprises that merely depend on the cost advantage of labor force and to bring more enterprises to the track of depending on technical progress and industrial escalation to strive for long term development, which will necessarily play a facilitating role in accelerating the progress of transferring the economic development mode." (Yi Bing \& Yue Shui, May 10, 2011)

Currently, we need to follow the following requirements for implementation of the collective bargaining at the level of industry. Firstly, we need to speed up the pace of legislation, and define the legal status of industrial collective bargaining. Under the circumstance when legislation at the level of the country can not be put into effect temporarily, local legislation may go first. Secondly, we need to integrate industrial trade union organizations and strengthen organization construction to make the cadres of the trade union have representativeness and the capacity of bargaining. Thirdly, it is also necessary to cultivate an employer organization corresponding with the trade union of the industry, reform the current employer association, construct employer trade union of the industry and make it have an industrial collective bargaining with the trade union on behalf of the employer.

\section{Concluding Remarks}

As a result of insufficient theoretical research in the collective bargaining system, deficiency in the system design and inadequacy in the thinking of the two parties of laborers and capital, the laborers and the employers fail to give full play to the initiative of the two parties in dealing with labor and capital affairs. As a consequence, the collective bargaining system is merely a formality and the system fails to play its due role in coordinating labor and capital relationship and protecting the legal rights and interests of laborers. In the recent few years, although we have been attempting to endow the laborers with more rights by means of formulating laws and regulations, this, to certain extent, has counteracted the obvious effects we have achieved in the reform of the labor law as we fail to straighten out and construct comprehensively the collective bargaining system.

\section{References}

Chang, K., \& Zhang, D. R. (1993). General Theory of the Trade Union Law. Party School of the Central Committee of the CPC Press.

Cheng, Y. Y. (2008, December 20). "Three Labor Rights": The Basis of Constructing Modern Labor Law. Retrieved from http://blog.sina.com.cn/s/blog_49a963b10100beq0.html

Dong, B. H. (2007). Reflections on the Harmonious Labor Relations. Journal of Shanghai Normal University, (Philosophy \& Social Sciences Edition).

Liu, H. S. (2010). Confirmation on Legislation of the Right to Strike. Theory Learning, 10. 
Special Research Group of Harbin City Federation of Trade Unions. (2007). Survey on the Working Condition of the Trade Unions after Restructuring of Enterprise. Harbin Gong Yun, 2.

Wang, J. (2011, April 26). Construction of Collective Bargaining System and the Three Labor Rights. Workers Daily.

Wang, J. L. (2009). A Game Analysis of Dilemma in Chinese Collective Bargaining. Heilongjiang Social Sciences, 2 .

Wang, L. (2008). Study on Collective Bargaining System in the Progress of a Harmonious Society. Master Thesis of East China Normal University, p. 46.

Wang, Q. (2006). Improvement on the Collective Bargaining System in China --- Reconstruction from the Perspective of Labor-Capital Self-governing. Master Thesis of China University of Political Science and Law in 2006, p. 33.

Yi, B., \& Yue, S. (2011, May 10). Industrial Bargaining: Development Direction of Collective Bargaining in China. First Financial Daily. 